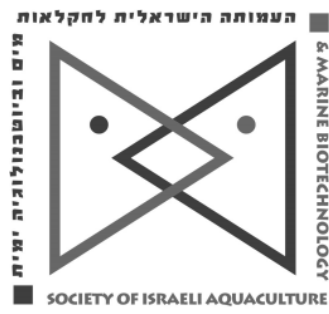

The IJA appears exclusively as a peer-reviewed on-line open-access journal at http://www.siamb.org.il. To read papers free of charge, please register online at registration form.

Sale of $I J A$ papers is strictly forbidden.

\title{
Growth of Wild Gilthead Seabream (Sparus aurata L.) Juveniles for Organic Aquaculture
}

\section{Fabrizio Capoccioni ${ }^{1}$, Michela Contò ${ }^{1}$, Sebastiana Failla ${ }^{1}$, Luca Buttazzoni ${ }^{1}$, Domitilla Pulcini* ${ }^{*}$}

${ }^{1}$ Consiglio per la ricerca in agricoltura e l'analisi dell'economia agraria - Centro per la produzione delle carni ed il miglioramento genetico - Via Salaria 31, 00015 Monterotondo Scalo, Rome (Italy)

Keywords: Coastal lagoons; gilthead seabream juveniles; lipid; organic aquaculture; PUFA, $\omega-3$

\begin{abstract}
The majority of organic marine fish farms currently begin the production cycle with nonorganic juveniles from conventional hatcheries, permitted by the European Regulation on organic fish origin (EC 710/2009) until the end of 2016. Wild juvenile gilthead seabream (Sparus aurata) from coastal lagoons and hatcheries were experimentally reared under organic conditions, in order (1) to investigate differences in fillet lipid content and fatty acids composition, and (2) to propose a possible future source of juveniles destined for organic aquaculture. Wild juveniles were readily distinguishable by their fatty acid signature, showing significantly higher ratio levels of n-3 polyunsaturated fatty acids and $n-3 / n-6$. Fillet lipid composition of organically fed wild $S$. aurata juveniles was preferable to that from domesticated juveniles. These results seem promising for organic aquaculture, where fish feed is more environmentally sustainable but is of lower nutritional quality.
\end{abstract}




\section{Introduction}

Attention has been focused on organic aquaculture due to a number of factors. Diminishing supply of fish (FAO, 2014), wild fish food-safety issues (Håstein et al., 2006), environmental concerns raised by conventional aquaculture practices (Perdikaris et al., 2016), increased fish consumption (FAO, 2014), forecasts on human population growth, and increasing market share of organic foods and acceptance of organic products by consumers. The development of organic aquaculture could play a pivotal role towards ecological and biological sustainability, maintaining a healthy aquatic ecosystem, respecting animal welfare, and producing high-quality food for human consumption. Organic fish marketing has expanded considerably, especially in Europe in the last decade (Bergleiter et al., 2009). Nevertheless, this branch of aquaculture is still in its infancy and faces a number of problems such as (1) scarce supply of certified organic juveniles, (2) rising feed cost, (3) high cost and the lack of uniformity in certification process, (4) limited market demand and (5) difficulty perceived by farmers of complying with organic rules (EC 710/2009). Until 2009 there was a lack of universally accepted standards and accreditation criteria regarding organic aquaculture. Thus, organic aquaculture remains a niche market; European countries produced 5,382 tons of organic fish (marine and freshwater fish, shellfish and crustaceans), accounting for just $0.3 \%$ of total European aquaculture production in 2014 (Eurostat, 2014). As organic aquaculture expands, more species are produced under certified programmes, and this growth is expected to increase in the future, reaching almost 1.2 million tons in 2030, equivalent to $0.6 \%$ of the total estimated aquaculture production (Lem, 2004).

The production cycle in most organic marine fish farms begins with non-organic juveniles from conventional hatcheries, a practice permitted until the end of 2016. Therefore, in order to allow for an increase in organic fish production, adequate sources of organic juveniles should be provided and appropriate organic broodstock should be available.

In order to promote sustainable aquaculture, fish meal and fish oil which are declining in availability and increasing in price, need to be replaced with alternative ingredients, from vegetable sources (Teles et al., 2001) and others (Chatzifotis et al., 2016). While replacement of up to $75 \%$ of the fish meal by plant proteins in sea bream diets does not reduce growth or protein retention (Sitja-Bobadilla et al., 2005), vegetable source based diets reduce fish flesh quality by lowering $n-3$ long chain PUFA content and the n-3/n-6 PUFA ratio (de Francesco et al., 2007), particularly in marine fish species. Some studies have reported that increasing levels of plant ingredients in diets for European sea bass (Gouveia and Davies, 2000) or gilthead sea bream (Pereira and Oliva-Teles, 2002), do not affect whole body lipid content or flesh quality (Aoki et al., 1996).

The aim of this study was to investigate nutritional attributes (i.e., lipid content and characterization) of gilthead seabream (Sparus aurata L) produced from wild and hatchery bred juveniles and reared under organic conditions in order to assess the effects of origin on the fatty acid profiles of fillets. This research focused on the lipid fraction of fillets, which represents the added value of seafood products and whose benefits to human health have been extensively documented (Calder and Yaqoob, 2009).

\section{Materials and methods}

Hatchery $(n=375)$ and wild $(n=75)$ gilthead seabream juveniles were stocked at NSAqua s.r.I. (Viterbo, Italy) in a closed re-circulating system of polypropylene rectangular tanks (50 L) for 10 months under natural photoperiod conditions. Temperature and salinity were constant at $20-21^{\circ} \mathrm{C}$ and $31 \%$, respectively.

Organic principles applied throughout the entire experiment. Conventional hatchery juveniles (initial mean weight $2.46 \pm 0.31 \mathrm{~g}$ ) were obtained from Valle $\mathrm{Ca}^{\prime}$ Zuliani Soc. Agricola s.r.l. (Rovigo, Italy). Wild juveniles (initial mean weight $<1 \mathrm{~g}$ ) were collected in the Caprolace coastal lagoon. This lagoon is part of the coastal Pontine lagoon system, within the Circeo National Park, located $100 \mathrm{~km}$ south of the city of Rome in Central Italy. It has been included in the Ramsar List of Wetlands of International Importance since 1978. The lagoon is $2.26 \mathrm{~km}^{2}$, with an average depth of $1.3 \mathrm{~m}$. During the trial, a group of fish was fed organic complete extruded feed for marine species, while a control group was fed a conventional complete extruded aquafeed. (See Table 1 for composition of feedstuffs). Feeding rations were calibrated according to producer indications (Naturalleva s.r.l. and Veronesi s.r.I.). 
Table 1. Proximate composition of commercial feedstuffs ( $\mathrm{g} / 100 \mathrm{~g}$ )

\begin{tabular}{|c|c|c|c|}
\hline & \multicolumn{2}{|l|}{ Organic aquafeed } & \multirow{2}{*}{$\begin{array}{l}\text { Conventional aquafeed } \\
\varnothing 1.8-2.2 \mathrm{~mm}\end{array}$} \\
\hline & $\varnothing 2.0 \mathrm{~mm}$ & $\varnothing 3.0 \mathrm{~mm}$ & \\
\hline & $\begin{array}{l}\text { Fish Meal, pea }{ }^{1} \text {, wheat }{ }^{1} \text {, fish } \\
\text { oil, vitamins and minerals }\end{array}$ & $\begin{array}{l}\text { Fish Meal, soybean panel, } \\
\text { pea }^{1} \text {, wheat }{ }^{1} \text {, fish oil, } \\
\text { vitamins and minerals }\end{array}$ & $\begin{array}{l}\text { Fish Meal, fish oil, soybean } \\
\text { meal, wheat meal, rapeseed } \\
\text { meal, vitamins and minerals }\end{array}$ \\
\hline Moisture & 7.7 & 6.7 & 9.0 \\
\hline Crude protein & 45.0 & 43.0 & 50.0 \\
\hline Crude fat & 13.0 & 15.0 & 21.0 \\
\hline Crude fiber & 1.8 & 2.9 & 1.0 \\
\hline Nitrogen free extract & 21.0 & 20.9 & 10.7 \\
\hline Ash & 11.5 & 11.5 & 8.3 \\
\hline $\mathrm{DP} / \mathrm{DE}(\mathrm{mg} / \mathrm{kJ})^{2}$ & 24.2 & 22.8 & 20.03 \\
\hline Vitamin C (poly-P) mg/kg & 1000 & 175 & 400 \\
\hline Vitamin A IU/kg & 9500 & 7000 & - \\
\hline Vitamin EIU/kg & 3000 & 2000 & 300 \\
\hline
\end{tabular}

${ }^{1}$ Organic

${ }^{2}$ digestible protein to digestible energy ratio

Three variables potentially affecting fish nutritional quality were tested: 1 ) aquafeed typology (conventional vs. organic); 2 ) origin of juveniles (hatchery vs. wild caught); 3 ) rearing density (12 $\mathrm{kg} / \mathrm{m}^{3}$, as recommended by EC 710/2009, vs. $6 \mathrm{~kg} / \mathrm{m}^{3}$ ). Each of these three variables were tested with 2 different cultural practices: 1) conventional or organic feed; 2) hatchery or wild juveniles; 3 ) high or low density. Due to a limited supply of wild juveniles not every combination of factors (low density) were applied to the wild juveniles. The control treatment consisted of hatchery juveniles fed with conventional aquafeed, and stocked at recommended density $\left(12 \mathrm{~kg} / \mathrm{m}^{3}\right)$. The experiment was performed in a rearing system with eight tanks. An incomplete factorial design with three treatments and a control was planned, each condition having two replicates. Hatchery juveniles were available in large quantities, thus both recommended and halved density groups were tested. Treatments are described in Table 2. In order to keep density constant, fish were removed when necessary during growth, and water volume was consequently adjusted.

Table 2. Description of treatments and abbreviations

\begin{tabular}{cccc}
\hline & Feed $(F)$ & Origin $(O)$ & Density $(D)$ \\
\hline $\mathrm{F}_{\mathrm{C}} \mathrm{O}_{\mathrm{H}} \mathrm{D}_{\mathrm{H}}$ & Conventional & Hatchery & Higher \\
$\mathrm{F}_{\mathrm{O}} \mathrm{O}_{\mathrm{W}} \mathrm{D}_{\mathrm{L}}$ & Organic & Wild & Lower \\
$\mathrm{F}_{\mathrm{O}} \mathrm{O}_{\mathrm{H}} \mathrm{D}_{\mathrm{H}}$ & Organic & Hatchery & Higher \\
$\mathrm{F}_{\mathrm{O}} \mathrm{O}_{\mathrm{H}} \mathrm{D}_{\mathrm{L}}$ & Organic & Hatchery & Lower \\
\hline
\end{tabular}

Fish were reared for 10 months, a period considered sufficient to obtain "organic juveniles" (EC 710/2009). At the end of the experiment, surviving fish were removed from each tank using a fine net, euthanized with a lethal dose of neutralized MS $222(\mathrm{pH} \mathrm{7)}$, and filleted. Fillets were stored at $80^{\circ} \mathrm{C}$.

Management and care of the animals was in compliance with the 86/609EEC European Union directive guidelines. Fish were collected according to good veterinary practice under farm conditions.

Analysis of lipids and fatty acids. Total lipids were extracted from $\sim 1 \mathrm{~g}$ of muscle tissue (previously freeze-dried) using chloroform/methanol solvent $2: 1(\mathrm{v} / \mathrm{v})$ as described by Folch et al. (1957). Lipid extracts were methylated using methanolic KOH according to IUPAC procedure. Gas chromatographic analysis was performed on a GC $6890 \mathrm{~N}$ (Agilent, Inc., California, USA) instrument. A CP-Sil88 capillary column (Supelco, 2560; $100 \mathrm{~m}, 0.25 \mathrm{~mm}$ (i.d.), $0.25 \mathrm{Im}$ film thickness) was used to analyse the methylated fatty acid content. Operating conditions were helium flow rate of 1 $\mathrm{ml} / \mathrm{min}$, FID detector at $300^{\circ} \mathrm{C}$, split-splitless injector at $250^{\circ} \mathrm{C}$ and injection volume of $1 \mu \mathrm{l}$. The 
temperature regime of the column was $4 \mathrm{~min}$ at $140^{\circ} \mathrm{C}$ with a subsequent increase to $220^{\circ} \mathrm{C}$ at $4^{\circ} \mathrm{C} / \mathrm{min}$ and then held at $220^{\circ} \mathrm{C}$ for $10 \mathrm{~min}$. The individual fatty acid peaks were identified by comparison with the retention times of a known mixture of standard fatty acids (FAME mix37; PUA-1 Marine Source; PUFA-3, Menhaden Oil, Supelco). Fatty acids were expressed as a percentage of the total methylated fatty acids (FAME).

Statistical analysis. Analysis of variance (ANOVA) was performed to test differences in fillet lipid content among treatments and between replicates.

Principal component analysis (PCA) was performed to investigate variations in fatty acid signatures among treatment groups and to identify the fatty acids mainly responsible for this variation. Data on fatty acid signatures (expressed as a percentage) were normalized using an arcsine square root transformation. Stepwise forward discriminant analysis was applied for crossvalidation (Lawson et al., 2001) and to test the efficiency of fatty acid data in identifying treatment groups. This approach begins with a preliminary model that includes the variables that best separate groups within the dataset. In forward selection, Wilk's lambda criterion (Mardia et al., 2000) was used to select new variables to be included in the model. The process ends when no new variable is able to improve the fitness of the model (Miller, 1984).

The variation in selected essential fatty acids among treatment groups and replicates was assessed using ANOVA tests. All statistics were performed using STATISTICA 7.0 (Statsoft).

\section{Results}

Mortality was negligible in all treatment groups. No significant differences were found in fillet dry matter among treatment groups and replicates $(75.7 \pm 1.2 \%)$. Differences between the four treatments in fillet lipid content were highly significant (ANOVA, $\mathrm{df}=3, \mathrm{~F}=55.98, p<0.001$ ), while differences between replicates were not (ANOVA, $p>0.05$ ) (Table 3). The lowest lipid content was found in the control group $\left(\mathrm{F}_{\mathrm{C}} \mathrm{O}_{\mathrm{H}} \mathrm{D}_{\mathrm{H}}, 2.1 \%\right)$ (conventionally fed, hatchery juveniles reared at recommended density, while the highest lipid content was found in organically fed, wild juveniles reared at halved density $\left(\mathrm{F}_{O} \mathrm{O}_{W} \mathrm{D}_{L}, 7.5 \%\right)$. Hatchery juveniles, organically fed and reared at both higher and lower density, $\left(\mathrm{F}_{\mathrm{O}} \mathrm{O}_{\mathrm{H}} \mathrm{D}_{\mathrm{H}}\right.$ and $\left.\mathrm{F}_{\mathrm{O}} \mathrm{O}_{\mathrm{H}} \mathrm{D}_{\mathrm{L}}\right)$, showed an average lipid content of $4.0 \%$ and $4.3 \%$, respectively.

Fatty acid signatures of all treatment groups are detailed in Table 3. Proportions of saturated fatty acids (SFAs) ranged from 23.7 to $26.7 \%$, with the highest value found for the $\mathrm{F}_{\mathrm{O}} \mathrm{O}_{H} \mathrm{D}_{H}$ group and the lowest found for the $\mathrm{F}_{\mathrm{O}} \mathrm{O}_{\mathrm{H}} \mathrm{D}_{\mathrm{L}}$ group. Palmitic acid (16:0) was the most common saturated fatty acid identified in all treatments followed by 14:0 (myristic acid) and 18:0 (stearic acid).

The proportions for monounsaturated fatty acids (MUFAs) ranged from $31.1 \%$ in the control group $\left(\mathrm{F}_{\mathrm{C}} \mathrm{O}_{\mathrm{H}} \mathrm{D}_{\mathrm{H}}\right)$ to $40.0 \%$ in the $\mathrm{F}_{\mathrm{O}} \mathrm{O}_{\mathrm{H}} \mathrm{D}_{\mathrm{H}}$ group. Of all MUFAs, $18: 1(\mathrm{n}-9)$ (oleic acid) was dominant in all groups, followed by $16: 1(n-7)$ (palmitoleic acid) and 18:1(n-7) (vaccenic acid).

The proportion of polyunsaturated fatty acids (PUFAs) was lower for groups with higher MUFA and/or SFA content. The highest levels of PUFAs were observed in the control group $\left(\mathrm{F}_{\mathrm{C}} \mathrm{O}_{\mathrm{H}} \mathrm{D}_{\mathrm{H}}\right)$. Among organically fed juveniles, wild juveniles $\left(F_{O} O_{W} D_{L}\right)$ showed the highest PUFAs contents, while the hatchery group reared at lower density showed the lowest.

Most prominent among identified PUFAs was 18:2 ( $n-6)$ (linoleic acid), whereas $n-3$ and $n-6$ PUFAs contents showed relatively little variation among treatments (Table 3 ). However, $n-3 / n-6$ ratios were significantly different among treatments $(p<0.001)$, with the control $\left(\mathrm{F}_{C} \mathrm{O}_{H} \mathrm{D}_{H}\right)$ and $\mathrm{F}_{\mathrm{C}} \mathrm{O}_{H} \mathrm{D}_{\mathrm{H}}$ showing higher $\mathrm{n}-3 / \mathrm{n}-6$ ratios (1.3). In contrast, $\mathrm{F}_{O} \mathrm{O}_{\mathrm{H}} \mathrm{D}_{H}$ and $\mathrm{F}_{\mathrm{O}} \mathrm{O}_{\mathrm{H}} \mathrm{D}_{\mathrm{L}}$ treatments displayed the lowest ratios, 0.9 and 0.8 respectively. 
Table 3. Lipid content and fatty acid composition (\% on total FAME) of fillets of S. aurata juveniles reared under different conditions

\begin{tabular}{|c|c|c|c|c|}
\hline & $H O_{r d}$ & $H O_{h d}$ & $H C_{r d}$ & $W O_{h d}$ \\
\hline & $\begin{array}{c}N=36 \\
\text { mean } \pm S D\end{array}$ & $\begin{array}{c}N=25 \\
\text { mean } \pm S D\end{array}$ & $\begin{array}{c}N=29 \\
\text { mean } \pm S D\end{array}$ & $\begin{array}{c}N=27 \\
\text { mean } \pm S D\end{array}$ \\
\hline Lipid content & $4.0 \pm 1.1 a$ & $4.3 \pm 1.0 a$ & $2.1 \pm 1.0 b$ & $7.5 \pm 2.9 c$ \\
\hline C14:0 & $3.7 \pm 0.3$ & $4.1 \pm 0.5$ & $3.8 \pm 0.6$ & $3.5 \pm 0.3$ \\
\hline C15:0 & $0.3 \pm 0.1$ & $0.4 \pm 0.0$ & $0.4 \pm 0.0$ & $0.3 \pm 0.0$ \\
\hline C16:0 & $15.3 \pm 0.9$ & $17.4 \pm 1.8$ & $17.4 \pm 0.8$ & $16.2 \pm 0.8$ \\
\hline C17:0 & $0.3 \pm 0.0$ & $0.3 \pm 0.1$ & $0.3 \pm 0.0$ & $0.3 \pm 0.0$ \\
\hline C18:0 & $3.7 \pm 0.3$ & $4.1 \pm 0.4$ & $4.4 \pm 0.4$ & $4.0 \pm 0.3$ \\
\hline C20:0 & $0.3 \pm 0.0$ & $0.3 \pm 0.0$ & $0.3 \pm 0.0$ & $0.2 \pm 0.0$ \\
\hline C21:0 & $0.2 \pm 0.0$ & $0.2 \pm 0.0$ & $0.2 \pm 0.0$ & $0.2 \pm 0.1$ \\
\hline \multirow[t]{2}{*}{ Total SFA } & $23.7 \pm 1.2$ & $26.7 \pm 2.8$ & $26.8 \pm 1.2$ & $24.6 \pm 1.3$ \\
\hline & $\mathrm{HO}_{\mathrm{rd}}$ & $\mathrm{HO}_{\mathrm{hd}}$ & $\mathrm{HC}_{\mathrm{rd}}$ & $\mathrm{WO}_{\mathrm{hd}}$ \\
\hline C16:1(n-7) & $4.7 \pm 0.3$ & $5.1 \pm 0.5$ & $4.2 \pm 0.8$ & $4.9 \pm 0.2$ \\
\hline $\mathrm{C} 18: 1(\mathrm{t}-11)$ & $0.2 \pm 0.0$ & $0.2 \pm 0.0$ & $0.2 \pm 0.0$ & $0.2 \pm 0.0$ \\
\hline C18:1(n-9) & $29.1 \pm 1.6$ & $31.2 \pm 2.5$ & $23.6 \pm 3.2$ & $26.4 \pm 1.3$ \\
\hline \multirow{2}{*}{ C18:1(n-7) } & $3.2 \pm 0.1$ & $3.5 \pm 0.2$ & $3.1 \pm 0.2$ & $3.2 \pm 0.1$ \\
\hline & $\mathrm{HO}_{\mathrm{rd}}$ & $\mathrm{HO}_{\mathrm{hd}}$ & $\mathrm{HC}_{\mathrm{rd}}$ & $\mathrm{WO}_{\mathrm{hd}}$ \\
\hline Total MUFA & $37.2 \pm 2.1$ & $40.0 \pm 3.1$ & $31.1 \pm 4.1$ & $34.6 \pm 1.5$ \\
\hline$C 16: 2(n-4)$ & $0.2 \pm 0.0$ & $0.2 \pm 0.0$ & $0.2 \pm 0.0$ & $0.3 \pm 0.0$ \\
\hline$C 16: 3(n-4)$ & $0.3 \pm 0.0$ & $0.3 \pm 0.1$ & $0.2 \pm 0.0$ & $0.2 \pm 0.0$ \\
\hline$C 18: 2(n-6)$ & $15.1 \pm 1.3$ & $13.3 \pm 3$ & $13.2 \pm 0.8$ & $14.2 \pm 0.6$ \\
\hline$C 18: 3(n-6)$ & $0.4 \pm 0.1$ & $0.3 \pm 0.1$ & $0.2 \pm 0.1$ & $0.4 \pm 0.1$ \\
\hline$C 18: 3(n-3)$ & $1.0 \pm 0.1$ & $1.0 \pm 0.1$ & $0.9 \pm 0.1$ & $0.8 \pm 0.0$ \\
\hline$C 18: 4(n-3)$ & $6.4 \pm 0.3$ & $5.9 \pm 0.6$ & $5.1 \pm 0.6$ & $5.7 \pm 0.7$ \\
\hline$C 20: 2(n-6)$ & $0.5 \pm 0.1$ & $0.4 \pm 0.1$ & $0.4 \pm 0.0$ & $0.5 \pm 0.0$ \\
\hline$C 20: 2(n-3)$ & $0.2 \pm 0.0$ & $0.2 \pm 0.1$ & $0.2 \pm 0.0$ & $0.3 \pm 0.0$ \\
\hline$C 20: 3(n-6)$ & $4.1 \pm 0.3$ & $4.3 \pm 0.5$ & $3.5 \pm 0.6$ & $3.2 \pm 0.4$ \\
\hline$C 20: 3(n-3)$ & $0.4 \pm 0.1$ & $0.3 \pm 0.1$ & $0.9 \pm 0.3$ & $0.6 \pm 0.1$ \\
\hline$C 20: 4(n-3)$ & $0.5 \pm 0.1$ & $0.4 \pm 0.2$ & $0.4 \pm 0.0$ & $0.7 \pm 0.2$ \\
\hline$C 20: 5(n-3)$ & $2.4 \pm 0.5$ & $1.7 \pm 0.7$ & $3.6 \pm 0.8$ & $4.0 \pm 0.3$ \\
\hline$C 22: 4(n-6)$ & $0.1 \pm 0.0$ & $0.1 \pm 0.0$ & $0.1 \pm 0.0$ & $0.1 \pm 0.0$ \\
\hline$C 22: 5(n-3)$ & $1.2 \pm 0.2$ & $0.8 \pm 0.4$ & $1.5 \pm 0.3$ & $1.8 \pm 0.1$ \\
\hline \multirow[t]{2}{*}{$C 22: 6(n-3)$} & $6.2 \pm 1.5$ & $4.2 \pm 1.7$ & $11.6 \pm 3.7$ & $8.0 \pm 1.1$ \\
\hline & $\mathrm{HO}_{\mathrm{rd}}$ & $\mathrm{HO}_{\mathrm{hd}}$ & $\mathrm{HC}_{\mathrm{rd}}$ & $\mathrm{WO}_{\mathrm{hd}}$ \\
\hline Total PUFA & $39.0 \pm 3.2$ & $33.3 \pm 5.7$ & $42.1 \pm 4.5$ & $40.8 \pm 2.2$ \\
\hline$\omega 3 / \omega 6$ & $0.9 \pm 0.1 a$ & $0.8 \pm 0.1 a$ & $1.3 \pm 0.2 b$ & $1.3 \pm 0.2 b$ \\
\hline
\end{tabular}

Values are mean \pm St.D. of the 26 fatty acids selected in the analysis. SFA: saturated fatty acids; MUFA: monounsaturated fatty acids; PUFA: polyunsaturated fatty acids. Table showed only principal fatty acids also selected in the analysis.

Principal component analysis separated groups along PC1 and PC2, explaining $88.5 \%$ of total variance (Fig. 1). PC1 accounted for $74.7 \%$ of the variance and was mainly made up by PUFAs $(22: 6(n-3), 24.0 \% ; 20: 5(n-3), 11.7 \% ; 22: 5(n-3), 7.3 \%)$ and oleic acid $(18: 1(n-9), 15.2 \%) . P C 2$ accounted for $13.8 \%$ of the variance and was mainly associated with $18: 2(n-6)(17.7 \%)$ and $16: 0$ $(13.7 \%)$ (Fig. 1a). Even when partially overlapped due to the high level of heterogeneity, experimental groups gradually separated along PC1: the positive extreme of the axis was almost exclusively characterized by hatchery juveniles fed a conventional diet (control $-\mathrm{F}_{\mathrm{C}} \mathrm{O}_{\mathrm{H}} \mathrm{D}_{\mathrm{H}}$ ) and wild fish fed an organic diet $\left(F_{O} O_{W} D_{L}\right)$. Organically reared juveniles at the two different stocking densities widely overlapped along the negative portion of PC1 (Fig. 1b). 
(a)

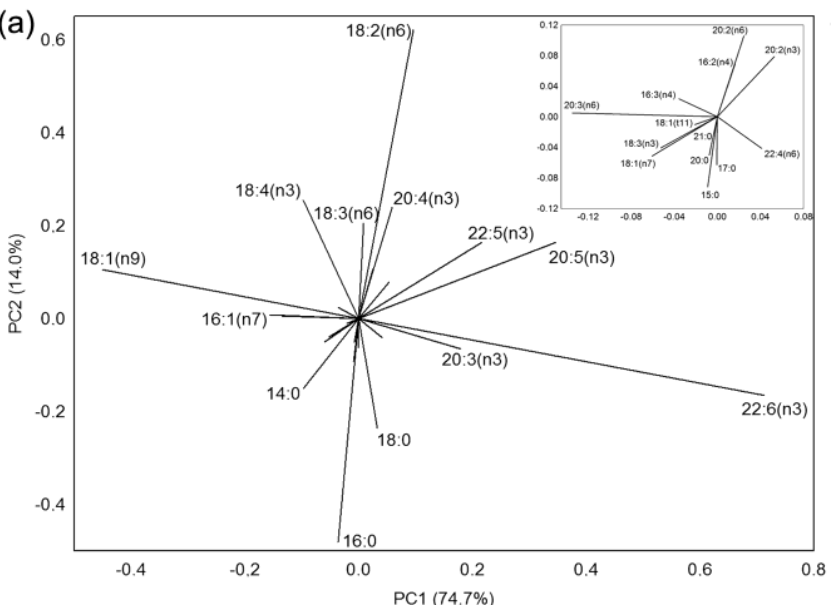

(b)

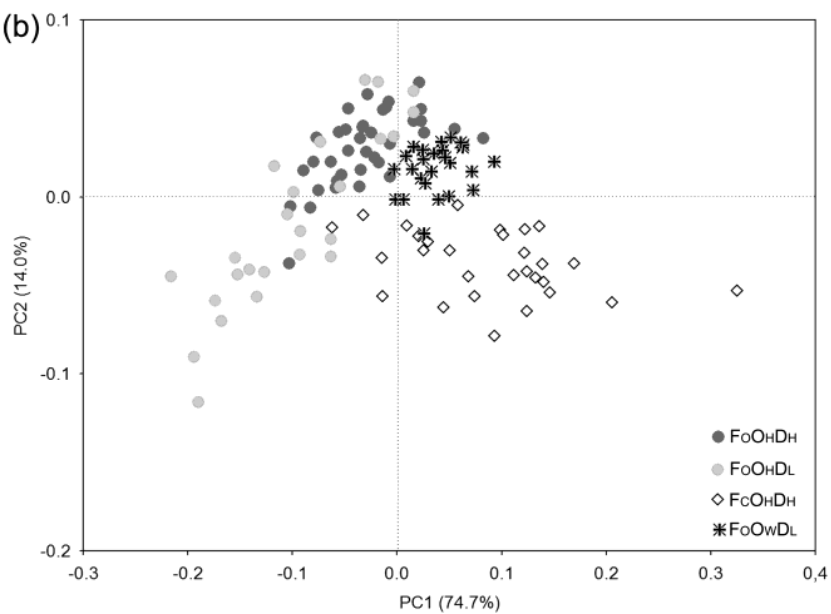

Fig 1. Principal component analysis of fatty acid composition of the four treatment groups studied. Analysis is based on the fatty acid signatures of 117 specimens, using the 26 fatty acids presented in Table 2. (a) Loading plots (principal and smaller scale enlargement) indicate fatty acids contributing to the distribution of sample data points in the score plot; (b) score plot indicating relationships between individual fish.

The stepwise forward discriminant model included 7 variables (FAs) (Wilks' Lambda $=0.009$; $\mathrm{F}=21.31 ; \mathrm{p}<0,001 ; 94.8 \%$ of variance explained) and separated group treatments with $92.4 \%$ correct classification rate. Misclassification occurred where a partial overlap in fatty acid signatures existed between treatment groups (see also Fig. 2), i.e. $\mathrm{F}_{O} \mathrm{O}_{H} \mathrm{D}_{H}$ and $\mathrm{F}_{O} \mathrm{O}_{\mathrm{H}} \mathrm{D}_{\mathrm{L}}$ displayed a lower percentage of correct classification ( 70.4 and $94.6 \%$, respectively) with a total of six and one fish assigned each in the other group. $\mathrm{F}_{\mathrm{C}} \mathrm{O}_{\mathrm{H}} \mathrm{D}_{\mathrm{H}}$ and $\mathrm{F}_{\mathrm{O}} \mathrm{O}_{\mathrm{W}} \mathrm{D}_{\mathrm{L}}$ displayed the best performance with 96.6 and $100 \%$ correct classification, with only one out of $29 \mathrm{~F}_{O} \mathrm{O}_{\mathrm{H}} \mathrm{D}_{\mathrm{H}}$ specimens incorrectly assigned in the $\mathrm{F}_{\mathrm{O}} \mathrm{O}_{\mathrm{H}} \mathrm{D}_{\mathrm{L}}$ group.

A selection of four FAs (one SFA: oleic acid, 18:1(n-9) and three PUFAs: EPA, 20:5(n-3); DHA, $22: 6(n-3) ;$ DPA, 22:5(n-3)) were chosen to be examined in depth due to their role in explaining total variance in PCA analysis (see loadings in Fig. 1a) and also for their importance in human health (Colman and Yaqoob 2009) (Fig. 2). The long chain n-3 essential PUFA (EPA, DHA and DPA) mean values found in organically fed wild juveniles $\left(F_{O} O_{W} D_{L}\right)$ and the hatchery group fed with conventional aquafeed $\left(\mathrm{F}_{\mathrm{C}} \mathrm{O}_{\mathrm{H}} \mathrm{D}_{\mathrm{H}}\right)$ were always higher than the organically reared hatchery groups $\left(F_{O} O_{H} D_{H}\right.$ and $\left.F_{O} O_{H} D_{L}\right)$. For EPA and DPA, wild fish reached the highest values, whilst for DHA, $F_{C} O_{H} D_{H}$ displayed the highest content. The increase of n-3 PUFAs (especially the most abundant DHA) in $\mathrm{F}_{\mathrm{O}} \mathrm{O}_{\mathrm{W}} \mathrm{D}_{\mathrm{L}}$ and $\mathrm{F}_{C} \mathrm{O}_{\mathrm{H}} \mathrm{D}_{H}$ fish fillets resulted therefore in a reduction of oleic acid, which is the main monoenoic fatty acid; it was found in significantly higher percentages in organically reared hatchery groups (31.2 and $29.1 \%$ for $\mathrm{F}_{O} \mathrm{O}_{H} \mathrm{D}_{\mathrm{L}}$ and $\mathrm{F}_{\mathrm{O}} \mathrm{O}_{H} \mathrm{D}_{H}$ respectively), whilst values were lower in conventionally fed fish $\left(23.6 \%, \mathrm{~F}_{C} \mathrm{O}_{H} D_{H}\right)$. Wild juveniles organically reared $\left(\mathrm{F}_{O} \mathrm{O}_{W} \mathrm{D}_{\mathrm{L}}\right)$ showed an intermediate percentage of $18: 1(n-9)(26.4 \%)$ (Fig. 2b). 
(a)
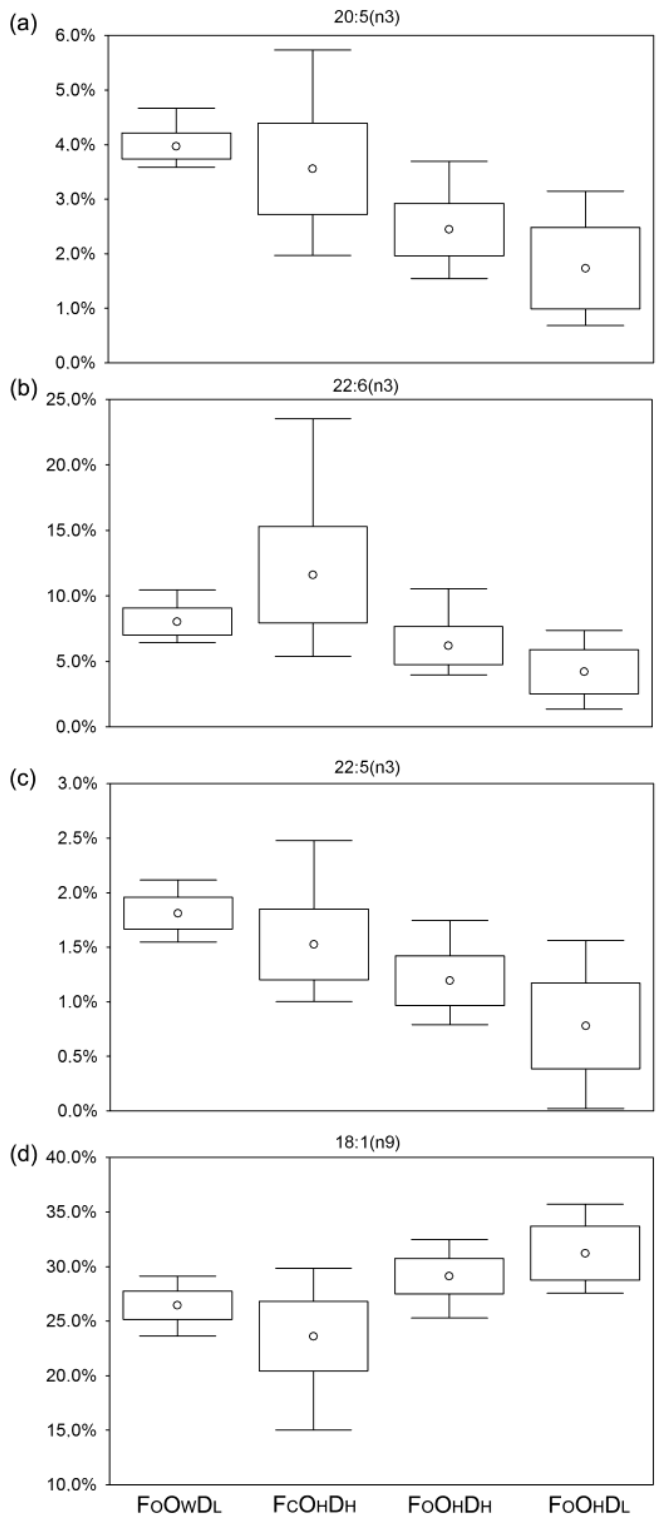

Fig 2. Percentages of four selected fatty acids in the treatment groups. (a) eicosapentaenoic acid (EPA); (b) docosahexaenoic acid (DHA); (c) docosapentaenoic acid (DPA); (d) oleic acid. The box-and-whisker plots give the mean values (dot), the standard deviation (box) and the minimum and maximum value (whiskers). Different letters $(a, b, c, d)$ denote significant differences among groups (ANOVA, $\mathrm{p}<0.05)$.

\section{Discussion}

Organically raised fish have only recently been offered to consumers, and organic aquaculture especially for marine species is in its infancy. Thus, organic broodstock and juveniles are still lacking. Possible supply alternatives, not from juveniles reared in non-organic hatcheries (allowed in decreasing percentages until 2016), are needed to increase production. The use of non-organic juveniles in organic production should be discouraged, as it conflicts with the principles of organic aquaculture regarding husbandry practices, stocking densities, and animal health management (EC 710/2009).

The present study focused on characterization of fillet lipid content and composition of gilthead seabream grown from juveniles collected in the wild and reared under organic conditions. This could determine if these juveniles are a suitable source for future organic aquaculture enabling an increase beyond current organic aquaculture limits, and therefore be a seafood product with nutritional attributes comparable to high-quality conventionally produced fish. Organic fish is often poor in essential fatty acids (Glencross, 2009).

The present study attempted to address the following questions: 1) Do wild, organically reared gilthead seabream juveniles, have a unique fatty acid signature compared with hatchery juveniles? 2) Are wild gilthead seabream juveniles grown under organic conditions richer in polyunsaturated fatty acids? The results of this study showed a higher total lipid content, and, in particular, higher PUFA percentage in wild juveniles fed organic aquafeed, compared to domesticated ones. As aquaculture continues to grow, there will be increased use of alternative lipid resources, in order to reduce 
dependence on marine-based lipid sources. It seems critical to investigate factors affecting PUFA levels in fish, given their role in fish welfare (i.e. immunity) and product nutritional quality (KrisEtherton et al., 2002).

We considered the possibility of establishing organic gilthead seabream broodstocks in coastal lagoons to supply the demand for organic juveniles. The present study found higher lipid content in fillets of gilthead seabream fed an organic diet compared with those fed conventional aquafeed. The results regarding the effect of diets containing plant protein ingredients on fat content of white muscle and liver in farmed fish are conflicting. A decrease in muscle/liver total lipid content in gilthead seabream fed a diet based either on soybean or rapeseed protein concentrates was observed (Mente et al., 2012), while others observed no effects (Pereira and Oliva-Teles, 2002; Güroy et al., 2012) or even an augmentation of lipid content (De Francesco et al., 2007). These differences in effects of vegetable protein sources on fat content in farmed fish are still under investigation, and are probably related to different lipid metabolism and plant protein source. The highest lipid content in muscle tissue in this study was observed in wild gilthead seabream organically fed, and kept at low density $\left(F_{O} O_{W} D_{L}\right)$. This result is open to speculation, since, as far as we know, it is the first time that wild sea bream juveniles have been used in organic on-growing experiments in direct comparison with hatchery ones. A possible explanation could be related to more efficient food assimilation and storage by wild specimens used to survival behaviour in natural conditions characterized by lower and unstable food availability in brackish water environments such as the Caprolace coastal lagoon (Tancioni et al., 2003).

Stocking density seemed to have a negligible effect on fat content, as no significant differences were found between hatchery fish at different stocking densities fed the same organic diet. A significant difference in lipid content between groups appeared to be unrelated to density and significantly related to diet and fish origin (Table 2 ). Stocking density has been found to be a growth-impairing factor, due to altered social interactions and deterioration of water quality which can affect both feed intake and conversion efficiency (Ellis et al., 2002). Several studies found that high densities (>30 kg/m $\mathrm{m}^{3}$ ) affect lipid metabolism and content (Di Marco et al., 2008). However, comparisons with the present results are not appropriate, as stocking densities were significantly lower $\left(<11 \mathrm{~kg} / \mathrm{m}^{3}\right)$ and the tissues examined varied (muscle instead of liver).

This study demonstrated that the majority of gilthead sea bream of different origin (wild $v s$ hatchery) and reared under different conditions (conventional vs organic diet) could be readily distinguished by their fatty acid signatures. In general the fatty acid composition in fish tissues reflects that of the diet (Glencross, 2009), but, as shown in this study, the origin of juveniles also seems to play an important role. Although other factors such as size, age, reproductive status, and season have been identified as possibly influencing fat content and composition of fish muscle (Saito et al., 1999), none of these factors have been considered in the interpretation of the results.

Even though hatchery and wild fish were fed the same organic diet, the $F_{O} O_{W} D_{L}$ group showed significantly higher levels of all selected n-3 PUFAs (Fig. 2a-c). Like most marine fish species, gilthead seabream have limited ability to convert C18 PUFA to long chain n-3 PUFAs, thus requiring preformed essential FAs in the diet (Mourente and Tocher, 1993). Wild fish reared in this study seemed to assimilate and store $n-3$ sources available in the diet better than their hatchery counterparts. The domestication process may explain this result: wild fish did not experience selective processes typical of captivity (i.e. relaxation of natural selection), maintaining adaptive skills lost through acclimatization to hatchery controlled and stable conditions (Ollivier, 1981; Price, 1988).

Among organically reared treatment groups, a significantly higher $n-3 / n-6$ ratio was found in the wild juvenile raised fish compared to their hatchery counterparts. It must be pointed out that the $n$ $3 / n-6$ ratio in wild caught juveniles was not significantly different from that observed in the control group fed conventional feed. PUFA levels and $n-3 / n-6$ ratio are dependent on aquafeed quality, so that extreme variation has been highlighted in previous studies comparing wild and farmed fish (Grigorakis et al., 2002; Orban et al., 2002). Fillet lipid composition of wild S. aurata juveniles organically fed in this study was superior compared to domesticated juveniles, even though the aquafeed used was the same for both groups.

Organic fish feed must be environmentally sustainable (EC 710/2009, art. 25k section c) but presents disadvantages in terms of nutritional value. In relation to the future of organic aquaculture our results are promising. Further studies are needed to investigate other aspects, such as effect of origin of juveniles on fish growth, the role of collection site of wild juveniles on fillet quality, and effects on future generations. Our results may encourage sustainable organic aquaculture and the sustainable management of transitional environments regarding organic fish production. 


\section{Acknowledgments}

Research was funded by the Ministero per le Politiche Agricole Alimentari e Forestali (SANPEI II Project). Authors would like to thank Dott. Valerio Vitalini from "Piscicoltura di Gaeta" who provided hatchery juveniles, the staff of the Ufficio Territoriale per la Biodiversità di Fogliano del Corpo Forestale dello Stato who helped us with the sampling procedures of wild juveniles, and Dott. Sergio Rabbai of the NSAqua facility who controlled the experimental rearing system throughout the trial. We thank Prof. Gary Thorgaard, who edited the manuscript.

\section{References}

Aoki H., Shimazu H., Fukushige T., Akano H., Yamagata Y. and T. Watanabe, 1996. Flesh quality in red sea bream fed with diet containing a combination of different protein sources as total substitution for fish meal. Bull. Fish. Res. Inst. Mie, 6:47-54.

Bergleiter S., Berner N., Censkowsky U. and G. Julià-Camprodon, 2009. Organic aquaculture 2009 - production and markets. Munich, Organic Services GmbH and Graefelfing, NaturlandeV.

Calder P.C. and P. Yaqoob, 2009. Omega-3 polyunsaturated fatty acids and human health outcomes. Biofactors, 35: 266-272.

Chatzifotis S., Sala-Pérez M., Guerra E., Santos Rodríguez L. and Ruiz-Navarro A., 2016. Dietary lecithin, nucleosides and krill do not affect growth performance and feed utilization of sharpsnout sea bream (Diplodus puntazzo) when added to a fishmeal-based diet, 11 pages. The Israeli Journal of Aquaculture - Bamidgeh, [IJA_68.2016.1313]

De Francesco M., Parisi G., Pérez-Sanchez J., Gomez-Réqueni P., Médale F., Kaushik S.J., Mecatti M. and B.M. Poli, 2007. Effect of high-level fish meal replacement by plant proteins in gilthead sea bream (Sparus aurata) on growth and body/fillet quality traits. Aquacult. Nutr., 13: 361-372.

Di Marco P., Priori A., Finoia M.G., Massari A., Mandich A. and G. Marino, 2008. Biological responses of European seabass Dicentrarchus labrax to different stocking densities and acute stress challenge. Aquaculture, 275: 319-328.

Ellis T., North B., Scott A.P., Bromage N.R., Porter M. and D. Gadd, 2002. The relationships between stocking density and welfare in farmed rainbow trout. J. Fish Biol., 61: 493-531.

Eurostat, 2014. Agriculture, Forestry and Fisheries. Fisheries. Aquaculture Production in tonnes and values. http://ec.europa.eu/eurostat.

FAO - Food and Agricultural Organization, 2014. The state of world fisheries and aquaculture. Opportunities and Challenges. Food and Agriculture Organization of the United Nations, Rome, 2014.

Folch J., Less M. and H.S. Stanley, 1957. A simple method for the isolation and purification of total lipids from animal tissues. J. Biol. Chem., 226(1): 497-509.

Glencross B.D., 2009. Exploring the nutritional demand for essential fatty acids by aquaculture species. Rev. Aquacult., 1: 71-124.

Gouveia A. and S.J. Davies, 2000. Inclusion of an extruded dehulled pea seed meal in diets for juvenile European sea bass (Dicentrarchus labrax). Aquaculture, 182: 183-193.

Grigorakis, K., Alexis M.N., Taylor K.D.A. and M. Hole, 2002. Comparison of wild and cultured gilthead sea bream (Sparus aurata); composition, appearance and seasonal variations. Int. J. Food Sci.Tech., 37: 477-484.

Güroy D., Tekinay A.A. and S. J. Davies, 2012. Use of organically certified yeast in the diet of juvenile rainbow trout (Oncorhynchus mykiss): growth performance, nutrient utilization, and fatty acid composition. Isr. J of Aquacult. - Bamidgeh, 64: 722-730.

Håstein T., Hjeltnes B., Lillehaug A., UtneSkåre J., Berntssen M. and A.K. Lundebye, 2006. Food safety hazards that occur during the production stage: challenges for fish farming and the fishing industry. Rev. Sci. Tech., 25: 607-625.

Kris-Etherton P.M., Harris W.S. and J. Lawrence, 2002. Fish consumption, fish oil, omega-3 fatty acids and cardiovascular disease. Circulation, DOI: 10.1161/01. 
Lawson G., Barange M. and P. Fréon, 2001. Species identification of pelagic fish schools on the South African continental shelf using acoustic descriptors and ancillary information. ICES $J$. Mar. Sci., 58: 275-287.

Lem A., 2004. An overview of the present market and trade situation in the aquaculture sector The current and potential role of organic products. Paper presented in Ho Chi Min City, Vietnam, 15-17 June 2004.

Mardia K.V., Kent J.T. and J.M. Bibby, 2000. Multivariate Analysis. Academic Press, Harcourt Science and Technology Company, London.

Mente E., Stratakos A., Boziaris I.S., Kormas K.A., Karazalos V., Karapanagiotidis I.T., Catsiki V.A. and L. Leondiadis, 2012. The effect of organic and conventional production methods on sea bream growth, health and body composition: a field experiment. Sci. Mar., 76 : 549-560.

Miller A.J., 1984. Selection of Subsets of Regression Variables. J. R. Stat. Soc.Series A(General), 147(3): 389-425.

Mourente G. and D.R. Tocher, 1993. Incorporation and metabolism of 14C-labelled polyunsaturated fatty acids in juvenile gilthead sea bream Sparus aurata L. in vivo. Fish Physiol. Biochem., 10: 443-453.

Ollivier L., 1981. Eléments de génétique quantitative. Masson, Paris.

Orban E., Nevigato T., Di Lena G., Casini I. and A. Marzetti, 2002. Differentiation in the lipid quality of wild and farmed seabass (Dicentrarchus labrax) and gilthead seabream (Sparus aurata). J. Food Sci., 68: 128-132.

Perdikaris C., Chrysafi A. and K.Ganias, 2016. Environmentally friendly practices and perceptions in aquaculture: a sectoral case-study from a Mediterranean-based industry. Rev. Fish. Sci. Aquacult., 4(2): 113-125.

Pereira T.G. and A. Oliva-Teles, 2002.Preliminary evaluation of pea seed meal in diets for gilthead sea bream (Sparus aurata) juveniles. Aquacult. Res., 33: 1183-1189.

Price E.O., 1998. Behavior genetics and the process of animal domestication. In: T. Grandin (ed.). Genetics and the behavior of domestic animals. Academic Press, New York.

Saito H., Yamashiro R., Alasalvar C. and T. Konno, 1999.Influence of diet on fatty acids of three subtropical fish, subfamily Caesioninae (Caesio diagramma and C. tile) and family Siganidae (Siganus canaliculatus). Lipids, 34: 1073-1082.

Sitja-Bobadilla A., Peña-Llopis S., Gomez-Requeni P., Médale F., Kaushik S. and J. Pérez-Sánchez, 2005. Effect of fishmeal replacement by plant protein sources on non-specific defence mechanisms and oxidative stress in gilthead seabream (Sparus aurata). Aquaculture, 249: 387-400.

Tancioni L., Mariani S., Maccaroni A., Mariani A., Massa F., Scardi M. and S. Cataudella, 2003.Locality-specific variation in the feeding of Sparus aurata L.: evidence from two Mediterranean lagoon systems. Estuar. Coast. Shelf Sci., 57: 469-474.

Teles A.O., Lupatsch I. and I. Nengas, 2001. Nutrition and feeding of Sparidae. Chapter 7. In: M. Pavlidis, C.C. Mylonas (eds.). Sparidae: Biology and aquaculture of gilthead seabream and other species. Wiley Blackwell, Oxford. 